\title{
Ambivalence regarding tuberculosis control actions in primary health care
}

\author{
Ambivalência das ações de controle da tuberculose na atenção básica à saúde
}

\author{
Ambivalencia de las acciones de control de la tuberculosis en la atención primaria de salud
}

\author{
Reinaldo Antonio Silva-Sobrinho ${ }^{1}$, Adriana Zilly ${ }^{1}$, Aline Aparecida Monroe ${ }^{2}$, Érika Simone Galvão Pinto ${ }^{3}$, Rosane \\ Meire Munhak da Silva ${ }^{1}$, Tereza Cristina Scatena Villa ${ }^{2}$
}

This study aimed to evaluate health professionals' perception regarding the organization and functioning of the Tuberculosis Control Program in Foz do Iguaçu, PR, Brazil. It is a qualitative study, in which the thematic axis was the structure and the centralization/decentralization of the control of tuberculosis. It was undertaken through open interviews, held in May 2009. Based on these, the empirical material was organized in the light of content analysis. The results revealed weakness in relation to the dimension of the physical structure and the human resources. Questions arose indicating Directly Observed Treatment as a paternalistic action. It was evidenced that there is a need for managers to take a position regarding the decentralization of tuberculosis control to Primary Health Care. However, the Central Thematic Unit revealed ambivalence relating to this theme. It is concluded that the Program, generally speaking, functions in line with the Ministry of Health's recommendations.

Descriptors: Tuberculosis; Health Public Policy; Decentralization; Primary Health Care; Border Health.

Objetivou-se avaliar a percepção dos profissionais de saúde sobre organização e funcionamento do Programa de Controle da Tuberculose em Foz do Iguaçu, PR, Brasil. Pesquisa qualitativa, que teve como eixo temático a estrutura e a centralização/descentralização do controle da tuberculose, realizada por meio de entrevistas abertas, ocorridas em maio de 2009. A partir delas, organizou-se o material empírico à luz da análise de conteúdo. Os resultados revelaram fragilidade em relação à dimensão da estrutura física e dos recursos humanos. Surgiram indagações que indicavam o Tratamento Diretamente Observado como uma ação paternalista. Evidenciou-se a necessidade de posicionamento dos gestores sobre a descentralização do controle da tuberculose para a Atenção Básica à Saúde. Contudo, a Unidade Temática Central revelou ambivalência quanto a esse tema. Concluiu-se que o Programa, de modo geral, funcionava conforme as recomendações do Ministério da Saúde.

Descritores: Tuberculose; Políticas Públicas de Saúde; Descentralização; Atenção Primária à Saúde; Saúde na Fronteira.

El objetivo fue evaluar la percepción de los profesionales de salud sobre organización y funcionamiento del Programa de Control de Tuberculosis en Foz do Iguaçu, PR, Brasil. Investigación cualitativa, con eje temático en la estructura y centralización/descentralización del control de la tuberculosis, realizada por medio de entrevistas abiertas, en mayo de 2009. De ellas, se organizó el material empírico a la luz del análisis de contenido. Los resultados revelaron debilidades en relación con la dimensión de la estructura física y los recursos humanos. Surgieron preguntas que indicaban el Tratamiento Directamente Observado como acción paternalista. Se señaló la necesidad de posicionamiento de los gerentes sobre descentralización del control de la tuberculosis para la Atención Primaria de la Salud. Sin embargo, la Unidad Temática Central reveló ambivalencia acerca de este problema. En conclusión, el Programa, de modo general, funcionaba según las recomendaciones del Ministerio de la Salud brasileño.

Descriptores: Tuberculosis; Políticas Públicas de Salud; Descentralización; Atención Primaria de Salud; Salud Fronteriza.

\footnotetext{
${ }^{1}$ Universidade Estadual do Oeste do Paraná. Foz do Iguaçu, PR, Brazil.

${ }^{2}$ Escola de Enfermagem de Ribeirão Preto, Universidade de São Paulo. Ribeirão Preto, SP, Brazil.

${ }^{3}$ Universidade Federal do Rio Grande do Norte. Natal, RN, Brazil.

Corresponding author: Reinaldo Antonio Silva-Sobrinho

Av. Tarquínio Joslin dos Santos, 1300 - Jardim Universitário. CEP: 85870-650. Foz do Iguaçu, PR, Brazil. E-mail: reisobrinho@unioeste.br
} 


\section{Introduction}

The year 2003 was a landmark for tuberculosis control in Brazil, as - in order to achieve the international goals of detecting $70 \%$ of the estimated bacillary cases and curing at least $85 \%$ of the diagnosed cases - the Ministry of Health added the control of the disease to the agenda of priorities for public policies $^{(1)}$.

The World Health Organization indicated that in 2010, 6.2 million cases of tuberculosis were notified worldwide, totaling 5.4 million new cases, corresponding to $65 \%$ of the estimated cases. In this period, Brazil had a gross rate of incidence and mortality of 37.6 and 2.4 cases per 100,000 inhabitants respectively, improving in the ranking of the 22 countries which concentrate $82 \%$ of cases of tuberculosis worldwide; even so, however, the disease continues to be a challenge for the Unified Health System ${ }^{(2)}$. Furthermore, in Foz do Iguaçu, in the State of Paraná (PR), the incidence of the disease was 41.8 cases per 100,000 inhabitants, reaching a cure rate of $67.3 \%$ and mortality of 1.6 cases per 100,000 inhabitants in the same period ${ }^{(3)}$.

Even considering the changes and pacts for the control of the disease, the data show that tuberculosis remains a serious public health problem, pointing to the need for implementation of the care in operational terms, principally in relation to greater detection of cases, reduction of the percentage of patients who default, and increase in the rate of cures ${ }^{(4)}$. As a result, with a view to ensuring the conclusion of treatment and the avoidance of multidrug resistance, in 1997, the component of Directly Observed Treatment was officially introduced in Brazil. This consists of the direct administration of the medication by a second person $^{(1)}$.

For the effective control of tuberculosis, it is necessary to have a healthcare model defined as a strategy. For this reason, the World Health Organization highlights the importance of the dimension of the organization and of the performance of the health services, stating that the problem is not in how the disease is detected or treated, but rather in how the health services are organized for detecting and treating the cases of tuberculosis ${ }^{(5)}$.

The Tuberculosis Control Program in Foz do Iguaçu/PR has mainly operated in an outpatient center in a centralized way, through the work of a specialized tuberculosis team, composed of two nursing technicians, one generalist nurse, one nurse who is a specialized in pulmonology health care and one general practitioner, offering attendance during regular business hours.

However, as it may be observed that in Foz do Iguaçu, the coefficient of incidence and mortality from tuberculosis is high, and the operational indicator of percentage of cure is below the $85 \%$ recommended by the World Health Organization, and as Foz do Iguaçu is a place where three international frontiers join, an investigation on the modus operandi of the strategy chosen for controlling the disease is relevant.

Considering this geographic, epidemiological and political-organizational context in health, this study aimed to evaluate the health professionals' perception regarding the organization and functioning of the Tuberculosis Control Program in Foz do Iguaçu, PR, Brazil.

\section{Method}

This is a descriptive, qualitative study, undertaken in May 2009 in the municipality of Foz do Iguaçu (PR), which is located by the Brazilian frontier with Paraguay and Argentina. The health care covers five health districts, in which there are 28 Primary Healthcare Centers, 32 Family Health Teams, two Emergency Rooms, one municipal radiology clinic, one outpatient center dealing with specialities, one municipal public hospital, three private hospitals which provide services to the Unified Health System, one outpatient center specialized in HIV/AIDS, and another which is a center of excellence for the 
treatment of tuberculosis ${ }^{(6)}$.

All of the local health services are gateways for persons suspected to have tuberculosis, and have autonomy to request the tests necessary for diagnosis. The principal locales sought are the Emergency Room and Primary Health Care. However, the Specialized Outpatient Center is the main service where detection of the cases takes place ${ }^{(6)}$.

In an attempt to implement the actions for controlling the disease in the Primary Healthcare Centers, the municipal management of the Tuberculosis Control Program promoted training for these workers. However, only five Primary Healthcare Centers complied. These started comprehensively to undertake the activities of diagnosis, treatment and monitoring of the patient through medical consultations, nursing consultations, and Directly Observed Treatment. However, after undertaking the actions of training and sensitization, the approach of referring suspected cases or already-diagnosed patients to the Specialized Outpatient Center continued to predominate among the municipality's other places of healthcare provision.

In this way, as a result of overburden of work, attendance hours of six hours per day, and the reduced number of professionals in the specialized center, the Directly Observed Treatment was undertaken only in the cases of patients with TB and HIV/AIDS coinfection, those receiving treatment after defaulting, and the homeless.

These health services also function as an informal service for a high population of Paraguayans and Brazilians who emigrated to Paraguay in the 1970s, who lack health care in that country, as well as a certain number of Argentinians, reflecting the great asymmetry in health in the triple frontier region ${ }^{(7)}$.

The study population was composed of 10 health professionals (nurses, physicians and nursing technicians) of the Foz do Iguaçu Health Department, the inclusion criteria being: to participate in the management or care with the municipality's Tuberculosis Control Program. The interview's script included the following guiding questions: How is tuberculosis control processed in the municipality, based on the care focused on a centralized outpatient center with a specialized team? What are the political-administrative positioning and/or barriers considering the recommendation for decentralization of the control of the disease to Primary Health Care?

The technique of Content Analysis ${ }^{(8)}$, using the mode of Thematic Analysis, was used, which made it possible to organize the set of accounts given (each account is identified by the letter A, followed by sequential Arabic numerals) during the interviews for discovering the nuclei of meaning which make up the communication, whose presence or frequency can reveal important aspects for analyzing the organization and the functioning of the tuberculosis control program.

The interviews were held individually, and the accounts were recorded and transcribed in full with the permission of the subjects who participated in the study, through their signing of the terms of consent, in accordance with Resolution 196/96 (National Health Council). The research was approved by the Research Ethics Committee of the State University of West Paraná (Unioeste), under protocol N. 022/2009.

\section{Results}

The codification of the accounts resulted in the construction of two nuclei of meaning: "Inadequacies in the structure available for controlling tuberculosis (human and physical resources)"; and "The digression in the organization of the care for the person with tuberculosis". These nuclei of meaning allowed the construction of a Central Thematic Unit: "Ambivalence in relation to the maintenance of the centralization of the care and the need to incorporate tuberculosis control actions in Primary Health Care".

In relation to the "inadequacies in the structure available for controlling tuberculosis (human and physical resources)", the need for the involvement of a greater number of qualified professionals 
was ascertained among the accounts, as was the quantitative weakness of physical resources. Sometimes, the difficulty is caused by the service. We have provided intermittent supervision, on Mondays, Wednesdays and Fridays; however, there are difficulties with the transport. One day, the car is broken down, the next there is no driver. (A-1). On other occasions, we in the service are sure that the service is creating obstacles to the treatment, due to the lack of staff, a car, and/or a driver... (A-2). The indicators for tuberculosis are not good... There is low detection of respiratory symptoms... and the percentage of cure in Foz do Iguaçu is below the recommended parameters, I believe that we need more qualified people, and more resources... (A-3). One major obstacle is the insufficient number of trained professionals for technical support, planning and care, considering actions for tuberculosis at the municipal level (A-3).

In relation to the "digression in the organization of the care for the person with tuberculosis", accounts emerged regarding Directly Observed Treatment, centralization of care, decentralization as a municipal management policy, and ambivalence in relation to decentralization, including adherence to decentralization as a need to respond to external pressure.

Attention is called to considerations produced regarding Directly Observed Treatment in the following account; For the people who are responsible and conscientious, who take responsibility for their treatment, what would the advantages of Directly Observed Treatment be? It would be a demonstration of a relationship of mistrust... When we would arrive there at around nine or 10 o'clock, the person had spent up to this time without having breakfast, and she could have taken the medication... and already got to work. In a case like this, does Directly Observed Treatment help or hinder? (A-2).

In some accounts, a position favorable to the centralization of the program was observed. The service uses are attended monthly in the service... with medical and/or nursing consultations. The medication is dispensed in the outpatient center itself, so there is no need to wait in line at the pharmacy... The radiological tests and sputum smear test are all undertaken here. The first sample for the sputum smear test is collected here in the first consultation... everything is done in the same place (A-1). In the outpatient center, we have pots for collection of sputum, forms, a fridge, availability of materials for the Mantoux test, and medications.
Some Primary Healthcare Centers do try to do the tuberculosis diagnosis and treatment, but the bulk is done here (A-4).

The process of change in the offering of health programs and services includes the managers' involvement and positioning. The managers lack sensitization such that the strategy of decentralization of tuberculosis may occur effectively. We have not been successful in the process of full decentralization of the tuberculosis control actions, this involves political and administrative decisions (A-5).

The ambivalence (implicit in the accounts) related to the possibility of decentralization; ...The program's operational difficulties, such as the low rate of detection, high default rates... are extremely concerning and require the problem to be faced more seriously by the professionals, the governments in all their spheres, by institutions and by the population as a whole, but I have my doubts as to whether decentralization is the right path (A5). ... For decentralization to occur, it is fundamental to promote the training of the family health teams, especially the community health workers (A-6). I don't know if decentralizing is good, there are cases which it doesn't help (A-5).

In the contents of the accounts below, the need for decentralization as a response to the guidance received from the political-administrative spheres external to the municipality appears clearly, as does the verbalization of the need for planning in order to advance towards the proposal of decentralization. I think it is necessary to implement the decentralization of the tuberculosis control actions, the State Health Department and the Ministry of Health have pressured the municipality to do this (A-6). It would be important to seek a partnership with the Coordination for the Center for the Control of Zoonotic Diseases for the insertion of the active search for cases in the visits made by the health workers who investigate endemic diseases... In partnership with the people from the social services and the municipality's Universities, when considering decentralization, as we have been pressured to do this (A-5).

\section{Discussion}

Considering the Emergency Plan, in Paraná, the inductive strategies consisted of passing the maximum financial support possible for Epidemiology and Control of Diseases ${ }^{(9)}$ on to the priority municipalities 
to encourage the control of tuberculosis. With this support, the municipality of Foz do Iguaçu-PR increased its physical structure, human resources, the quality in the biosecurity of the tuberculosis outpatient center and integration with Primary Health Care, encouraging the search for cases and the referral of these to the specialist outpatient center, with the centralization of the care prevailing as the organizational logic.

Currently, the organization of tuberculosis care is heterogeneous in Paraná; some municipalities transfer the care responsibilities for control of the disease to Primary Health Care while others remain centralized. A similar movement was also ascertained in municipalities in the state of São Paulo, resulting from the Ministry of Health's recommendations ${ }^{(10)}$. However, difficulties in incorporating tuberculosis control actions by Primary Health Care arose in the municipalities of the state of São Paulo which opted for decentralization ${ }^{(10)}$, thus there are no guarantees that this strategy will achieve the expected objectives ${ }^{(4)}$.

"The inadequacies in infrastructure available (human and physical resources) for the control of tuberculosis" and "The digression in the organization of the care for the person with tuberculosis, (evidenced by the changing of position in relation to Directly Observed Treatment and the model of care in tuberculosis found in the respondents' accounts)" were the main obstacles identified in the accounts relating to the context studied, which permeate the centralization/decentralization of tuberculosis control.

Emphasis should also be placed on the fact that the municipality is situated in the international triple frontier region, and is subject to attending an extra populational group, which seeks attendance in Brazil, due to the free character of the services of the Unified Health System, and this population influences and puts pressure on how financial resources are allocated and the way the local health system is organized(6).

Transport was observed to be among the problems in the functioning of the program, as the vehicle made available is also shared with another service, and invariably it is necessary to negotiate times for using it, leading to delays in the supervising of the Directly Observed Treatment. In these situations, the health professional cannot undertake the care appropriately, resulting in the loss of the services' capacity to resolve problems in the process of interacting with the tuberculosis patient, as well as the bond and adherence to the therapeutic process ${ }^{(10)}$. The impossibility of undertaking the planned activities promotes improvisation, frustration and discouragement.

The interviewees' concern in relation to the professionals' training for the planning and production of the care for the service user was noted; this is a fundamental aspect in tuberculosis care ${ }^{(4)}$. Training in tuberculosis has an important role and must ensure the understanding of the disease and its conditioning factors, as well as the instruments and technologies used in its prevention and control ${ }^{(10)}$.

Added to professional training, the supervision of the treatment has been proven to be effective in controlling the disease; however, it presupposes the involvement of the managers, health professionals and community, such that an increase in the effectiveness of the program may occur in an articulated way ${ }^{(4)}$.

In one study undertaken in priority municipalities in the state of São Paulo, accounts were identified relating to resistance to the incorporation of Directly Observed Treatment, it being the case that some professionals perceive Directly Observed Treatment as labor-intensive and a paternalistic act $^{(10)}$. In Dourados, in the state of Mato Grosso do Sul, however, this strategy's strengths for adherence to treatment and increase in the percentage of cure were ascertained ${ }^{(4)}$. For the control of tuberculosis, such a conception is concerning, as it may compromise peoples' adherence to the drug treatment. Furthermore, adherence depends on the bond and the embracement provided by the health professionals to the patient during the practice of treating tuberculosis ${ }^{(11)}$. 
Another organizational aspect, which relates to the position that the tuberculosis care must obligatorily take place in specialized services, has been an obstacle for incorporating the control of the disease into Primary Health Care, a situation exacerbated by the health teams, which see tuberculosis care as the exclusive competence of the specialized services; which contributes to Primary Health Care not taking responsibility in the control of the disease $\mathrm{e}^{(10)}$.

It stands out that tuberculosis care in Primary Health Care and in the specialized services can coexist, due to the existence of complementary activities between these. In relation to these services' performance, in Campina Grande-PB, the following were observed: the absence of divergences in the quality, in particular in relation to the time taken to achieve a consultation within 24 hours, having to miss one's shift at work to make the consultation, and having to wait more than 60 minutes to be attended ${ }^{(12)}$.

In relation to Directly Observed Treatment, this occurs with greater frequency in the Primary Healthcare Centers than in the specialized outpatient center, the patients undergoing treatment in the specialized outpatient center needed to spend money on transport to travel there more frequently than the patients treated in Primary Health Care ${ }^{(12)}$. The decentralization of the health actions triggered in the Unified Health System presents strengths and weaknesses, and the control of tuberculosis is situated in this context.

One account indicated that decentralization had not yet been successful due to political-administrative obstacles. The postponing of the discussions regarding the directions of the control of this endemic disease in the municipality may be explained by the position which the issue occupies in the political-managerial agenda (the government's political commitment) in Brazil $^{(13)}$, beginning from the decision-making and executive level; as a result of which, tuberculosis has been neglected as an issue.

This discussion, however, is composed of a set of juridical-legal proposals which have been undergoing consolidation in Brazil since the creation of the Unified Health System, which seeks to make the municipality the manager of the health actions. The decentralization of tuberculosis originates in this process $^{(13)}$.

The forms of providing the care, and intervention strategies adopted in the health systems, are influenced and change in particular due to the managers' planning and administrative and political positioning ${ }^{(14)}$. The managers must be sensitized to the importance of managerial strategies in confronting the chronic conditions, such as tuberculosis ${ }^{(10)}$. It is well known, however, that there is discontinuity in the administrative posts, whether political or assistential, hindering the undertaking of the management processes initiated previously.

Experiences involving the decentralization of tuberculosis control actions have shown the existence of weaknesses/barriers, due to knowledge gaps, which compromised the undertaking of specific aspects of the strategies; however, significant advances were made, with emphasis on the structure (human and physical resources) in some scenarios ${ }^{(4,14)}$.

The decentralization of the health activities is a complex issue and involves the political-managerial dimension, the training of the professionals, intersectorialization, the financing of the actions, the ordering of the information system, the organization of the flow of referral and counter-referral for diagnostic support tests and specialties in the context of a healthcare network.

Broadening the scope of the work of Primary Health Care requires caution, planning, and a strategy of gradually transferring responsibility, given that the undertaking of the control actions does not depend only on altruism and engagement, but on teams which are qualified to assist persons with a complex disease $^{(10,15)}$.

Besides the discussion regarding the difficulties of organizing tuberculosis control in the municipal ambit, it is appropriate to add that Foz do Iguaçu-PR, as it is a city on the international triple frontier, faces 
complexity in health issues linked to the planning of joint strategies for controlling infectious diseases in transnational spaces, where peoples' coexistence is constant, without territorial demarcation, but with access to different health services which do not communicate with one another.

Different studies have shown asymmetries in the financing and joint organization of health strategies between health systems between neighboring countries, even among countries which are signatories of economic treaties, such as the European Union and Mercosur. These differences are evidenced when there is internal transit of the populations in these territories, in particular when the individual sees more effective assistance being provided outside his own country, causing organizational difficulties for the health systems attended, given that these are managed to meet internal demand ${ }^{(6,16)}$.

It stands out that the demand for health services in Brazil from Paraguayans, Argentinians and Brazilians who have emigrated to these countries occurs in emergency units, specialized services, and also in the Primary Healthcare Centers. As a result, it is appropriate to viabilize a shared strategy for the surveillance, diagnosis and treatment of tuberculosis among the municipalities of the triple frontier, given the presence of territorial inequalities in health. Due to this, it is urgent to adjust the health systems, so as to offer innovative responses capable of resolving the health issues ${ }^{(6)}$.

Preserving the principles and guidelines of the Unified Health System, and the philosophy of the Family Health Strategy, Primary Health Care would be a privileged locus for tuberculosis control, broadening its scope for action beyond the idea of attending clients from a particular area and territoriality, when dealing with transfrontier spaces. It is also necessary to consider the need for making agreements and formalizing projects for cooperation in public health, detailing the sources of finance, responsibilities, and duties between the countries involved.

\section{Final Considerations}

The program is organized, and functions, based on the Ministry of Health's operational and clinical norms. There are, however, difficulties in undertaking it, causing some recommendations to be adapted to the municipality's context.

The centralization of the tuberculosis control actions in an outpatient center hinders access which could resolve the health problem in the search for attention and care focused on the family and community. The Directly Observed Treatment has been undertaken only for extremely vulnerable patients, as there are obstacles, such as transport and lack of human resources.

Questions to be resolved relating to tuberculosis control were evidenced, due to the magnitude and complexity of the care, and consequently, due to the organization of the care, in this scenario which demands harmony between the managers, tuberculosis control program coordinators, Primary Health Care professionals, and society, for the elaboration of a collaborative care project, which may be plausible and workable in the environment of the international triple frontier, devised considering social rights and access to health.

\section{Acknowledgments}

Planning Office for Research and Postgraduate Studies at the State University of West Paraná, for their financial support.

\section{Collaborations}

Silva-Sobrinho RA, Monroe AA and Villa TCS participated in the conception and elaboration of the project, data analysis, editing and critical analysis of the article. Zilly A, Pinto ESG and Silva RMM contributed to the production of the scientific article. 


\section{References}

1. Santos J. Brazilian response to tuberculosis control. Rev Saúde Pública. 2007; 41(supl 1):8993.

2. Ministério da Saúde (BR). Secretaria de Vigilância em Saúde. Boletim Epidemiológico. Especial tuberculose. [Internet] Brasília: Ministério da Saúde; 2012 [citado 2012 out 02]; 43: 1-12. Disponível em: http://portal.saude.gov.br/portal/ arquivos/pdf/bolepi_v43_especial_tb_correto.pdf.

3. Ministério da Saúde (BR). Sala de situação em saúde. [Internet] Brasília: Ministério da Saúde; 2011. [citado 2014 jan 26]. Disponível em: http://189.28.128.178/sage/

4. Amaral AS, Tamaki EM, Sales CM, Renovato RD. Avaliação da descentralização do programa de controle da tuberculose do nível secundário para o nível primário do sistema de saúde de DouradosMS. Saúde Soc. 2010; 19(4):794-802.

5. World Health Organization. WHO report 2009: global tuberculosis control: epidemiology, strategy, financing. Geneva: WHO; 2010.

6. Silva-Sobrinho RA, Andrade RLP, Ponce MAS, Wysocki AD, Brunello ME, Scatena LM, et al. Retardo no diagnóstico da tuberculose em município da tríplice fronteira Brasil, Paraguai e Argentina. Rev Panam Salud Pública. 2012; 31(6):461-68.

7. Jiménez RP, Nogueira VMR. La construcción de los derechos sociales y lós sistemas sanitarios: los desafíos de las fronteras. Rev Katál. 2009; 12(1):50-8.

8. Bardin L. Análise de conteúdo. Lisboa: Edições 70;
2009.

9. Ministério da Saúde (BR). Portaria $\mathrm{n}^{\circ} 2306$, de 4 de dezembro de 2003. Acresce recursos ao teto financeiro de epidemiologia e controle de doenças - TFECD e dá outras providências. Brasília: Ministério da Saúde; 2003.

10. Monroe AA, Cardozo-Gonzales RI, Palha PF, Sassaki CM, Ruffino-Netto A, Vendramini SHF, et al. Envolvimento de equipes da atenção básica à saúde no controle da tuberculose. Rev Esc Enferm USP. 2008; 42(2):262-67.

11. Freitas KG, Sobrinho ECR, Piai TH, Figueiredo RM. Family health nursing assistants knowledge on tuberculosis. Rev Rene. 2013; 14(1):3-10.

12. Figueiredo TMRM, Villa TCS, Scatena LM, CardozoGonzales RI, Ruffino-Netto A, Nogueira JA, et al. Performance of primary health care services in tuberculosis control. Rev Saúde Pública. 2009; 43(5):825-31.

13. Villa TCS, Assis EG, Oliveira MF, Arcêncio RA, Cardozo-Gonzales RI, Palha PF. Cobertura do tratamento diretamente observado (DOTS) da tuberculose no estado de São Paulo (1998 a 2004). Rev Esc Enferm USP. 2008; 42(1):98-104.

14. Protti ST, Silva LMC, Palha PF, Villa TCS, RuffinoNeto A, Nogueira JA, et al. Managing the basic health unit in tuberculosis control: a field of challenges. Rev Esc Enferm USP. 2010; 44(3):66570 .

15. Feitoza DS, Clares JWB, Rodrigues LV, Almeida PC. Epidemiological surveillance in the context of the tuberculosis control program: limits and Possibilities. Rev Rene. 2012; 13(5):1066-74.

16. Queiroz LG, Giovanella L. Mercosur's regional health agenda: architecture and themes. Rev Panam Salud Publica. 2011; 30(2):182-88. 